\title{
Europe extends biotech grants 'experiment'
}

Paris. On the basis of the apparent success of a pilot project, the European Commission is to delegate to the scientific community the management of four biotechnology projects funded by the European Union (EU)'s Fourth Framework research programme. But the body responsible for the pilot project says it no longer proposes to carry out the initial selection of research proposals.

The commission's move extends an experiment started two years ago within the third Framework programme, under which a consortium known as A Molecular Initiative in Community Agriculture - or AMICA has managed an ECU24 million (US\$18.5 million) Priority Technological Programme (PTP) on Plant Molecular Genetics for an Environmentally Compatible Agriculture (see Nature 366, 291; 1993).

The consortium is led by the John Innes Institute in Norwich (United Kingdom) and the Max Planck Institute in Cologne (Germany). According to one commission official, it is too soon to say whether delegation of the programme's management has improved its scientific output. But from an administrative point of view the test case has "worked well and quickly" in getting grants to scientists and recruiting staff, he says.

Many researchers agree. "AMICA's management has been very efficient," says Jean Dénarié, a researcher at the CNRS/INRA Molecular Biology of Interactions between Plants and Microorganisms laboratory in Toulouse.

Another advantage, say researchers, is that whereas EU programmes have previously consisted of many small consortia usually made up of five laboratories AMICA coordinates all 117 laboratories taking part in the PTP within four 'networks' grouped around 18 research themes.

\section{India keeps the squeeze on science budget}

New Delhi. For the third year in a row, money for research and development will be scarce in India's government laboratories and universities next year, as the budget for 1995-96, published last week, provides only a small increase in funds for science.

The 37.7 billion rupees (US $\$ 1.2$ billion) allocation - omitting 9.4 billion rupees spent on defence research - is 3 billion rupees more than last year. But the increase is likely to be less than the rate of inflation, now running at 11.5 per cent.

Pleas by prominent scientists for more research and development funding appear to have gone unheeded by the government, whose term of office ends next year. A large proportion of the budget has been allocated to populist programmes such as alleviation of poverty, rural development and benefits to farmers - all likely to boost the ruling party in the general elections.

On the basis of such positive responses, the commission says it intends to extend the AMICA model of delegated management to the successor to the current PTP, the plant and animal biotechnology programme. It will also be applied to three other projects within the biotechnology programme: the cell factory, genome analysis and cell communication in the neurosciences.

A bid from AMICA to run this next plant biotechnology programme would be "most welcome", says one commission official, adding that other bids would also be considered for both this and the other programmes following an open call for proposals which the commission will make in the autumn.

Jeff Schell, director of the Max Planck Institute, says that AMICA will apply to run the new programme, but it will not propose that the consortium should also carry out the initial peer review and selection of pro-
Munich. A sharp conflict about whether industry should have more control over the work of Germany's state-funded national research centres was defused last week at a meeting between government officials, directors and union representatives from two major national research centres, and industry representatives.

In 1993, the ministry of research and technology - now known as the Bundesministerium für Bildung und Forschung (BMBF) - commissioned a study of industrial relevance of the research at the national centres.

The study was conducted by a group led by Hartmut Weule, head of the research division of Daimler-Benz, and focused on

Apart from a token grant for the proposed superconducting LINAC booster for research in heavy-ion nuclear physics, the only new project for which money has been approved this year is a DNA fingerprinting centre, to be set up at Hyderabad. The centre will provide fingerprinting services for both criminal investigations and settling paternity disputes, using an indigenously developed DNA probe.

Unlike the previous two years, the budget squeeze will have no adverse effect on the Council of Scientific and Industrial Research (CSIR), India's largest research agency with about 40 laboratories, which earns substantial funds from industrial contracts.

But other agencies will not be so lucky, and will receive only enough funds to maintain existing projects. "There will be a complete slackening of research in universities," says one scientist.

K.S.Jayaraman

\section{Germany defuses conflict over labs}

jects. An attempt by AMICA to do so in 1993 provoked controversy, while half of the projects it selected were eliminated by the EU's own peer-review process.

Schell admits that there was much opposition to AMICA's attempt to take responsibility for selecting projects. But he says its decision not to apply for this role in the next Framework programme was taken only because it would be unable to "do the job well" within the available time. "We don't want to lose our credibility, and play into the hands of critics," he says.

Nevertheless, Dénarié and other scientists are concerned about the "principle" of allowing consortia of scientists to select projects. "It would be unimaginable for the National Science Foundation (NSF) to hand over selection of grants to a small committee made up of representatives of just several US universities." Declan Butler

the two largest of Germany's 16 national research centres, the Forschungszentrum Jülich (KfA) and the Kernforschungszentrum Karlsruhe (KfK), both of which have applied and basic research programmes.

It found about 30 per cent of work in the two centres was relevant to industry - and recommended that this be increased to $\mathbf{7 5}$ per cent over a five-year period (see Nature $372,4 ; 1994)$. But the Weule commission is now backtracking on the 75 per cent figure; Wolfgang Scheunemann, a spokesman for the commission, says that it was not intended literally.

It has now been agreed that communication between the two sides should be increased, in particular at the planning stages of research projects. Joachim Treusch, KfA director, says the number of industrial scientists on advisory committees, as well as their voting rights, has already been increased at his institute, and will be further increased.

But behind the publicly expressed harmony, it remains unclear whether the industrialists and the national research centres really see eye-to-eye on what they each mean by "strengthening" applied research. The two national research centres agree that they need to strengthen certain applied research programmes, but not necessarily that they should increase the total number of applied research programmes, says Treusch.

Additional measures to increase collaboration between industry and the national research centres, such as exchange of scientists between the two, are being discussed. A further meeting is scheduled in May.

Toni Feder 